\title{
Thinking of the New Accounting Standard Systems on the Fair Value
}

\author{
Ming-e Cheng, Yang Tang \\ School of Economics and Management, Henan Polytechnic University, P.R.China,454003 \\ Cme331@hpu.edu.cn
}

\begin{abstract}
The ministry of finance in February 15, 2006 release, including one principle and 38 specific standards of the new accounting standards system, in many aspects to realize the new breakthrough, including the use of fair value measurement attribute is the most striking aspect. In this paper, the new accounting standards in fair value concept, the use of fair value and the fair value of application of thinking about three aspects to carry on the analysis, this paper put forward own corresponding opinions.
\end{abstract}

Index Terms - New accounting standard Systems, Fair value

\section{Concept of Fair Value}

The accounting standards for enterprises - basic standards. "chapter 9 in the provisions of article 42 in fair value measurement, assets and liabilities under the fair trade, familiar with the situation of the transaction between parties asset exchange or the amount of debt discharge measurement. Fair value is also called the fair market value, fair prices, familiar with the situation of buyers and sellers in the fair transaction conditions determined price, or no associated in the fair transaction both sides under the condition of an asset can be business clinch a deal price. GAAP generally accepted accounting principles of fair value is defined as the fair value of the assets is in the clearing transactions, voluntary trade both sides to buy or sell an asset of the current value; The fair value of the liability is in the clearing transactions, voluntary trade both sides occurrence or pay a debt of the current value. The so-called fair value, its essence but is based on subjective judgment qualitative factors have greater than quantitative standard quantitative factors. The determination of the fair value, need to rely on accounting personnel's professional judgment, to understand the definition of fair value measurement attribute, should consider to:

\section{A. Fair Trade Fair Value is the Premise of the Formation}

The fair value of the original meaning is fair market price, its predecessor is the market value or the market price. In 1952, in koehler the accounting dictionary ", the fair value of explanation is: fair value means "fair and reasonable value, this words are often used for utilities." The term is usually and fair market value in general use, therefore, we can put the fair trade the basic conditions summed up as follows: one is the buyers and sellers for the exchange of equal independent subject; The second is both parties engaged in and property transfer or services provide relevant activities, shall, in accordance with the law of value of the objective requirements of equivalent exchange; The third is the purpose of the exchange of normal commercial consideration, related party between the transfer price, the enterprise liquidation process of liquidation prices are not included; The fourth is both parties are familiar with the market, and forced to voluntarily rather than on the Commodity Exchange.

\section{B. Perfect Market and Perfect Market - Fair Value Market Assumption}

The so-called perfect market is to point to: goods and claim trading is zero transaction costs cases happen; Any enterprise or individual, does not have to earn supra-normal returns special advantage or opportunities; The price is not with any individual or enterprise behavior and change. The socalled perfect market is to point to: all of the goods or claims have corresponding market exists, any goods or claim market prices are open the can check. At this time, the market transaction price approximately reflect the fair value, because the market participants will have risk factors into consideration, such as to determine the trading price. Because of this, the fair value, market foundation, market foundation value, the market price is often regarded as synonyms. Perfect market one of the means of buyers and sellers of information to is symmetrical, it is very important for market transaction. Because only the mastery of the complete information, transaction have fair may.

\section{The Fair Value of the Theory Support - Net Surplus Theory}

Fair value is in the economics of the concept of value accounting express, is to reflect the current value of the accounting elements essential characteristics of the concept of reflected, fair value accounting is based on value and the value of the accounting. It is the modern financial accounting concept framework first deductive logic, which prompted accounting assets, accounting income to economics assets and economics earnings regression foundation. The benefits of economics based on physical capital preservation basis, including not only in order to achieve the basis of accounting income, including unrealized value changes; Not only consider the transaction, the influence of considering the influence of the transaction. Economic benefits according to the final opening of the net assets of the balance sure, what reflect is the current value or the basis of its fair value of assets and liabilities view. Practice proved that economic benefits than accounting earnings more comprehensive, profit affiliates' decision has more relevance. Phil gaza and olsen net surplus theory provides a consistent view and measurement framework, thus further for the fair value measurement 
provides the theory support. Net surplus theory is that, when all the gains and losses are through the income statement reflect, enterprise value can be expressed as the balance sheet of the enterprise assets to the net book value and future very profitable expected sum of present value. The carrying amount of the asset net value can be directly from a balance sheet, investors need to get information estimation is very profitable expected value, but because of the complexity of the market and bounded rationality, investors may not like information view assumed that skilled measuring out the current value of the future very profitable. Therefore requires the accounting personnel as complete and accurate to provide more relevant information about the carrying value of the assets, so as to provide to the investors decision-making useful information, namely accounting personnel have the responsibility to the current value or fair value is reflected in the financial statements in itself, in order to improve the financial statements of usefulness, this is the concept of accounting measurement. Therefore, net surplus theory and the derivative of accounting measurement view direct guide the fair value measurement.

\section{The New Accounting Standard Systems in the Use of Fair Value}

The ministry of finance issued the accounting standards for enterprises application guide "since, how to use fair value become a point of contention. First of all, the new accounting standards is still standing in the historical cost basis, and not all things with the fair value measurement. The historical cost method although cannot show that enterprise current market value, however, it can be objectively that forms the enterprise value of the material basis, and the authenticity and integrity of accounting measurement accord with the principle of prudence. Secondly, using fair value to have some restrictive conditions, for example, the use of fair value of assets to have the active market, can after the market price of similar assets or offer to estimate the fair value, in this case can use fair value.

The new guidelines 38 respectively for the enterprise different business does not specially set up a fair value, for which can use fair value, which can not apply, scattered in different business to provisions. At present our country has issued 38 specific accounting standards accounting elements involved in the measurement of 30 , in this 30 involves accounting elements measuring criteria in the fair value of a 17 specific standards, mainly including:

\section{A. Accounting Standards for Enterprises No. 3 - an Investment Real Estate}

Article 10 in there is any exact evidence showing that the fair value of the investment real estate can be obtained in a reliable and continuous case, may be made to the investment real estate through the fair value pattern to conduct the followup measurement. Measured through the fair value pattern, it shall satisfy the following conditions:

1) The investment real estate location is active trading market of real estate.
2) From the trading market of real estate enterprise can have the identical or similar real estate market price and other related information, and the fair value of the investment real estate to make reasonable estimation.

Article 11 measured through the fair value pattern, no investment real estate depreciation or amortization, shall be based on the balance sheet date, the fair value of the investment real estate basis adjust its book value, fair value and the difference between the original carrying value included in the current profits and losses.

B. Accounting Standards for Enterprises No. 2 - a LongTerm Equity Investment Business Combination not Under the Same Control, the Acquirer Shall Distribute According to the Accounting Standards for Enterprises No. 20 - Merger of Enterprises Determine the Combination Cost of the Long-Term Equity Investment as the Initial Investment Cost

Article 4 in addition to enterprise merger formation of a long-term equity investment beyond, other ways of a long-term equity investment obtained, shall, in accordance with the following provisions determine its initial investment cost:

1) To pay cash of a long-term equity investment obtained shall, according to the actual payment of the purchase price as the initial investment cost. The initial cost consists of the obtainment of the long-term equity investment directly related expenses, taxes and other necessary expenses, but the actual payment contains has declared but have not received cash dividend, it should be as receivables accounted for separately.

2) To issue equity securities of a long-term equity investment obtained, shall, in accordance with the issuance of equity securities of the fair value as the initial investment cost.

3 ) The investors invest long-term equity investment, shall, in accordance with the investment contract or agreement value as the initial investment cost, but the contract or agreement except the unfair value stipulated.

\section{Accounting Standards for Enterprises No. 4 - Fixed Assets}

Article 11 the investors into the cost of the fixed asset shall, according to the investment contract or agreement to determine the value of, but the contract or agreement except the unfair value.

\section{Accounting Standards for Enterprises No. 7 - Exchange of Non-Monetary Assets}

Article 4 the non-monetary assets exchange at the same time meet the following a piece, shall be based on fair value and relevant payable taxes of the change as the cost of the assets, fair value and the carrying value of the assets surrendered the difference between the profits and losses of the current period:

1) the exchange is commercial in nature;

2 ) in the assets or the fair value of the assets surrendered can be measured in a reliable way.

Swap in assets and assets surrendered all fair value can be measured reliably, it shall be the fair value of the assets surrendered as confirmed in the assets the basis of cost, unless 
there is any exact evidence showing that the fair value of the assets in more reliable.

\section{E. Accounting Standards for Enterprises No. 10 - Enterprise Annuity Fund}

Article 6 an enterprise annuity fund operation according to the provisions of the state in the scope of investment, achieved national debt, credit rating in the investment grade above financial bond and QiYeZhai, convertible bonds, investment of insurance products, securities investment funds, stocks, etc liquid financial products, the initial and subsequent valuation shall be made on the basis of their fair values:

1) obtained initial investment, it shall pay the price by trading day clinch a deal as its fair value enter an item in an account. Happen transaction cost directly included in the current profits and losses.

2) the valuation day to investment valuation, with its fair value shall be adjusted the original book value, fair value and the difference between the original carrying value included in the current profits and losses.

\section{F. Accounting Standards for Enterprises No. 11 - Share- based Payment}

Article 8 to rights equity-settled share-based payment in return for goods or other service, shall be respectively the following circumstance processing:

1) goods or other the fair value of the service of can be reliable meter $t$, it shall be made with its and the fair value of the relevant payable taxes as the cost of goods or other services, the owner's equities shall be increased accordingly.

2) the goods or other service of the fair value cannot be reliably measured but fair value of the equity instruments can be measured reliably, shall be based on the fair value of the equity instruments and relevant payable taxes of the as in exchange for goods or other service cost, owner's equities shall be increased accordingly.

Article 10 a cash-settled share-based payment, it shall bear the liabilities of the fair and equitable value measurement.

\section{G. Accounting Standards for Enterprises No. 12 - Debt Restructuring}

Article 5 the debtor pay off debts by non-cash asset, the debtor shall book value of the debt will be restructured and the fair value of the non-cash asset transferred the difference between the identified as debt restructuring gains, and shall be recorded into the profits and losses of the current period.

Fair value of the non-cash asset transferred and the difference between the book value, confirmed as assets transfer profit and loss, and shall be recorded into the profits and losses of the current period.

Article 6 the debt is converted into capital, the debtor shall creditors will abandon the claim and enjoy the total par value of shares, recognized as the stock of capital (or paid-in capital), the total amount of the fair value of the shares of capital (or paid-in capital) to recognize the difference between the capital reserves.

The book value of the debt restructuring and the fair value of the shares the difference between the total, recognized as the debt restructuring gains, and shall be recorded into the profits and losses of the current period.

\section{The Fair Value of the Use of Thinking}

\section{A. By Using Fair Value Accounting in China Marked the International Convergence of Substantial Step}

The country's new the accounting standards for enterprises - basic standards "clearly will be fair value accounting measurement attribute as one, and in 17 specific accounting standards in different degree using the measurement attributes, this shows that the Chinese to the international convergence of accounting made substantive step. The fair value of the widely used, means that our country traditional single historical cost measurement model is the historical cost, fair value measurement attribute such multiple coexist replaced the measurement model. Our country in the basic accounting standards in China is introduced and decisive in specific accounting standards extensive use of fair value measurement attribute, showing the international convergence of accounting in our country the substantial progress, but also fully reflects the international convergence of accounting in China realize the confidence and determination.

\section{B. Fair Value Use is Our Country Market Economy Matures the Important Symbol}

Market economy as a kind of mechanism, is our country since the reform and opening up to realize rational allocation of resources and the rapid economic development of the engine, China is the participation in the economic globalization competition basic conditions. Accounting as a market economy important infrastructure, service and must be subject to the allocation of resources and the need of economic development. In the early economic transformation, due to the state-owned economy in our country economy accounting for subject even absolute control position, entrusted with the responsibility report performance naturally become the first accounting target. Accounting target long-term is defined as first of all to meet the needs of the macroeconomic management, the other is regarded as minor. However, with multiple financing joint-stock enterprise's development, especially the listed company a large increase, the rapid development of capital markets, making accounting goal by mainly for the government macroeconomic management to provide reliable information, steering for investors, creditors and other major information the user's decision to provide relevant information. However, in the basis of reliability, to improve the relevance of accounting information quality is the inevitable requirement. Because of its fair value can be fair to reflect the enterprise's financial position and operating results, and other information, have been recognized as improving accounting information correlation important measurement attributes. Expand the capital market, the development of market economy, objectively need to make use of fair value measurement attribute. 


\section{Use Fair Value Accounting Standards is also Played in the Capital Market Infrastructure is the Inevitable Requirement of Function}

Our country accounting standards of production and development, to a great extent, is due to the development of capital market. Can say, is the development of capital market led China's accounting standards. Modern capital market is built on the basis of information disclosure, with reliability and relevance of accounting information is the capital market healthy and orderly development of the necessary condition. The historical cost measurement attributes although because has the "verification" trait has been in our country's accounting standards unify the whole country, but it can only reflect the assets or liabilities past value, and to meet the accounting information users the future decision-making needs. This makes based on this processing generated accounting information usefulness sell at a discount greatly. Obviously, simply the pursuit of the reliability of accounting information will greatly reduce the usefulness. Only with reliability, have relevance of accounting information can really play a maintenance investors, creditors and the role of social public benefit, so as to promote the healthy and stable development of capital market.

\section{Perfect Our Country's Fair Value Accounting Theory System}

The basic accounting standards in our country the status and effect of the "conceptual framework with foreign similar", in order to guide the formulation of specific standards. But, our country's specific standards system is still in its initial period, "shall have the advantage of backwardness". In addition, along with the social economic environment changes and development of accounting basic theory know deep constantly, basic criterion revision it seems only a matter of time before. Therefore, in the revision basic accounting standards, the fair value of content to write one basic rule, one is about specific standards can avoid the repetitive; The second is the specific criteria can enhance the systematic and theoretical persuasion; The third is to specific standards propaganda, study and implement. Specific standards by using fair value to deal with the details of detail should as far as possible to rules or instructions, at the same time with using robust principle, the fair value accounting model of Achilles' heel is poor reliability. Especially in China, the accounting information distortion is relatively serious, accountant professional judgment experience is relatively lack. In view of these considerations, as far as possible need detailed accounting norms, so that we can reduce the plaster statements behavior, but also to the practice operation.

\section{E. Improve Accountant have Excellent Professional Judgment Ability}

Fair value is generally a market value or the current value of the future cash flow, its measurement, relative to the historical cost is concerned, in addition to have series of external conditions of use outside, need more accountants have excellent professional judgment ability. From the technical level speaking, high quality for the fair value, not only need accountants has a wealth of accounting theory and practice quality, also need to accountant understanding evaluation, finance, capital market and other related knowledge, otherwise, the judgment can imagine as a result.

Due to the new accounting business constantly emerging, some common business also no corresponding standards to regulate, can foresee the future there will be many business involves the fair value, so we must speed up the pace of the standard setting, Through the establishment of good corporate governance structure and internal control system, to strengthen enterprise management constraints, improve accounting personnel's service quality; Establish supervision department regular inspection system, expand audit personnel team, give full play to the CSRC, registered accountants, the state auditing department function, abuse of fair value of enterprise and prompt the, executives to strict supervision, and constantly improve the criminal law, such as the accounting law and fair value related laws, give offender to criminal punishment, civil penalty and administrative punishment, to deter they use fair value profit manipulation of psychology, can give the implementation of fair value to create a good environment.

\section{Conclusion}

The ministry of finance in February 15, 2006 release, including one principle and 38 specific standards of the new accounting standards system, in many aspects to realize the new breakthrough, including the use of fair value measurement attribute is the most striking aspect. In this paper, the new accounting standards in fair value concept, the use of fair value and the fair value of application of thinking about three aspects to carry on the analysis, this paper put forward own corresponding opinions.

\section{References}

[1] The accounting standards for enterprises 2006 the ministry of finance of the People's Republic of China for economic science press, 2006.2 (In Chinese)

[2] The accounting standards for enterprises - application guidelines for the ministry of finance of the People's Republic of China financial and economic publishing house 2010.1 (In Chinese)

[3] In the new accounting standards of the fair and equitable value measurement using the analysis of wang ling jiao "development research $>2011.3$ (In Chinese) 